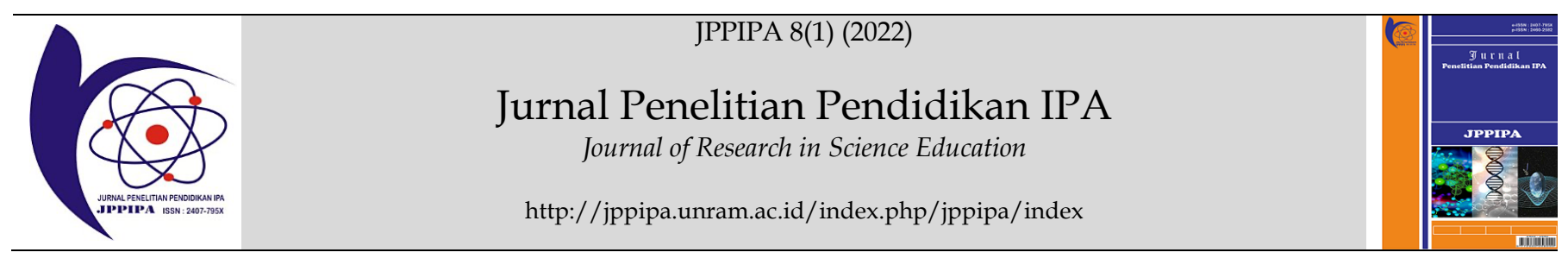

\title{
Developing PTS Device (pH, TDS, and salinity) to Determine the Water Quality for Cultivating Milkfish (Chanos chanos Forsk) in Pati District
}

\author{
Fina Fakhriyah ${ }^{1,2^{*}}$, Putut Marwoto ${ }^{2}$, Edy Cahyono ${ }^{2}$, Retno Sri Iswari ${ }^{2}$ \\ ${ }_{1}^{1}$ Primary Educational Teacher Department, Universitas Muria Kudus, Indonesia \\ ${ }^{2}$ Postgraduate Department, Universitas Negeri Semarang, Indonesia
}

\section{DOI: $\underline{10.29303 / \text { ippipa.v8i1.1043 }}$}

\section{Article Info}

Received: October 16, 2021

Revised: January 20, 2022

Accepted: January 24, 2022

Published: January 31, 2022

\begin{abstract}
The importance of water management for milkfish cultivation determines the yields. This research aims to find the performance specification and $\mathrm{pH}$, TDS, and Salinometer measurement (PTS) design validity and relevance. These tools are combinations from various sensors connected by Arduino nano 328 system, $\mathrm{pH}$ meter analogue, turbidity, and salinity measurement sensors complemented by Liquid Crystal Display and battery. They are connected by data cable. The findings showed that 1) the system's performance specification was applying copper electrodes as the salinity, turbidity, and $\mathrm{pH}$ meter sensors. The Arduino system did the readings of the data. 2) the device-design specification was valid and relevant to measure the pond water quality for cultivating milkfish (Chanos chanos Forsk).
\end{abstract}

Keywords: Water quality; pH; Turbidity; Salinity; Milkfish

Citation: Fakhriyah, F., Marwoto, P., Cahyono, E., \& Iswari, R. S. (2022). Developing PTS Device (pH, TDS, and Salinity) to Determine the Water Quality for Cultivating Milkfish (Chanos chanos Forsk) in Pati District. Jurnal Penelitian Pendidikan IPA, 8(1), 362-370. https:// doi.org/10.29303/jppipa.v8i1.1043

\section{Introduction}

The cultivation of milkfish (Chanos chanos) plays a major role in driving the people's economy in coastal areas (Andriyanto, 2013). Globally, milkfish production is ranked 9th in the amount produced and accounts for $3.63 \%$ of world aquaculture production but does not include China (Chai, et al. 2019). Mirera (2011) revealed that milkfish cultivation has attracted a lot of attention for marine fish farming in East Africa because it tolerates a wide range of environmental conditions, as well as the availability of seeds from nature. Milkfish is one type of fish that is widely consumed by people in Indonesia, this is because milkfish is easy to find and has a delicious taste and has an affordable price. In addition, according to (Tang, et al. 2010; Edwards, 2015; Hu, et al. 2015) milkfish (Chanos chanos forsk) is a type of fish that has a high degree of adaptation to the environment.

For cultivating milkfish, the water quality has important role in a successful yield. The condition of water influences the dietary pattern of milkfish. Milkfish farmers have to check or control the water condition several times a day at least twice a day, in the morning and the evening. The water condition should be observed regularly, starting from the salinity, dissolved oxygen content, $\mathrm{pH}$, alkalinity, and watercolour (brightness). By finding out the water condition, for example, poor water condition, farmers could immediately take countermeasures (Taslihan, et al. 2005). Farmers usually could find it visually or by using measuring devices. Visually, it could be done by observing the appearing watercolour and the behaviours of milkfish. The water would seem greener and darker due to algae, phytoplankton, and zooplankton growth in the water. Observation of water quality on milkfish pond could be done using measuring devices, such as refractometer, DO meter, $\mathrm{pH}$ meter, and Secchi disk (Rachmatun \& Mujiman, 2011). A refractometer is used to measure the content or dissolved material concentration. Siltri, Yohandri \& 
Kamus (2016) revealed the refractometer mechanism and the principle of light refraction. Light refraction happens when light passes two mediums with different densities. This bias index will be counted as salinity content (Shirley, 2005).

The water quality could also be measured by the DO meter. DO meter is used to measure the oxygen content of a liquid and functions as an absolute parameter to assume water quality. The dissolved oxygen in water comes from phytoplankton's photosynthesis process or plants in water (Mariyam, et al. 2017). In water, oxygen has the role of oxidizing and reducing chemical materials into simpler compounds as the required nutrient for water organisms. The primary oxygen source is estimated from the free air diffusion process and photosynthesis process products (Salmin, 2005). Alava (1998) and Hanke et al. (2019) state that a decrease in temperature outside the optimal range can also reduce DO in water so that it increases water salinity conditions which can trigger a stress response in milkfish so that milkfish growth experiences decrease and affect the productivity of milkfish cultivation.

The next device to measure water quality is the $\mathrm{pH}$ meter. It is a device to measure the content of acid or the base of the water. $\mathrm{pH}$ measurement is the main determinant factor for aquatic biota sustainability in a pond. The soil quality influences the $\mathrm{pH}$ of pond water. Thus, the new pond surely has a lower $\mathrm{pH}$ or acid situation. Cultivating milkfish requires checking the water regularly. It is to avoid the sudden death of the fish. It is because fish is sensitive to $\mathrm{pH}$ changes. Milkfish farmers regularly change the pond water by flowing the water to the sea and vice versa. Esmiyati et al. (2012) also revealed the water management conducted by pond farmers. One of them was maintaining the water quality to make the milkfish grow better and had a delicious taste.

Besides that, milkfish farmers also need a device called a Secchi disk. It is a simple device for measuring water transparency in the sea or lake. Secchi disk is a coloured-disk plate (it is mostly a two-coloured plate, black and white). An excellent quality condition for milkfish pond water is critical. Milkfish pond water is a brackish water ecosystem. The salinity of brackish water is found in seawater, freshwater, dynamic water salinities. Various changes could occur based on parameters of chemical, physics, or biological changes. Changes could be seen from season to seasonally, monthly, daily, or hourly (for example tidal wave). The changes are caused by biological processes occurring in the water and interaction between pond water and the surrounding environment. For example, when it rains, water floods the pond and decreases the salinity of the pond. The other phenomena occurring in the biological process changes are fertilization and oxygen content in the pond water during the evening that drastically shrinks. They may occur within hours and insist the farmers make the required countermeasures to prevent interruption for the cultivated milkfish and increase the yields' production. The farmers are expected to make regular notes about their observations. Thus, the messages will be handy because any negative matter they underwent in the ponds might have occurred again. This is confirmed by the opinion of Riani \& Indra (2016) which states that to get efficiency, milkfish farmers must significantly optimize their production factors.

Based on the observation about cultivated milkfish in Bakaran Wetan, Juwana, Pati, showed that most farmers measured water quality by visually observing. It was called "ilmu titen" or "Predicting Skill" traditionally. They also used one simple device, hydrometer salinity. The farmers usually use it to measure the salinity of water in water temperature. Based on the observation about cultivated milkfish in Bakaran Wetan, Juwana, Pati, showed that most farmers measured water quality by visually observing. It was called "ilmu titen" or "Predicting Skill" traditionally. They also used one simple device, hydrometer salinity. The farmers usually use it to measure the salinity of water in water temperature. The shape of the device is shown in Figure 1.

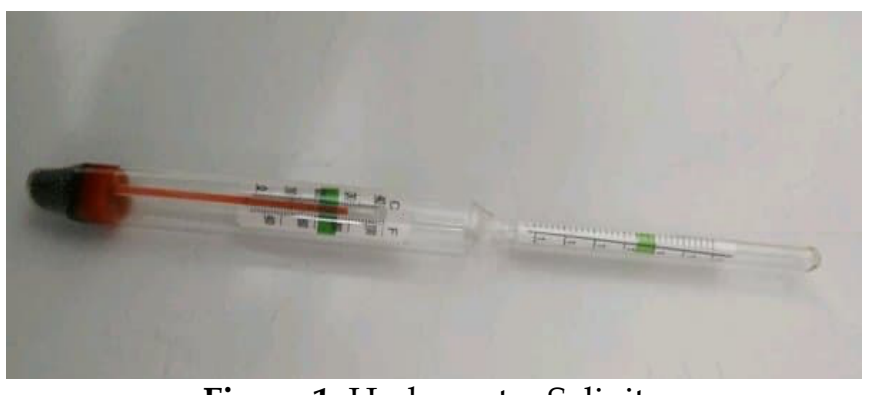

Figure 1. Hydrometer Salinity

Heretofore, hydrometer salinity, shown if Figure 1, is used to measure the pond's salinity and water temperature in a simple manner. Some farmers might not have this device. Measuring the salinity and temperature were done by drowning the device in pond water. Then, farmers checked the indicating numbers (shown in Figure 1). The weakness of this measuring method was - requiring carefulness so that the device would not fall in the pond (and brought by the wave into the middle pond). According to the farmers in Bakaran Wetan, Juwana, Pati, this was effective. However, the accuracy of the farmers to read the device was not maximum. Besides that, farmers had to measure other matters, such as $\mathrm{pH}$ and turbidity of the water. Unfortunately, the farmers never completely completed the water quality due to limited devices and unintegrated functions. 


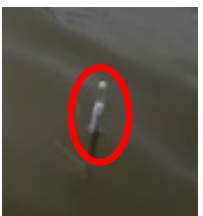

Salinity hydrometer (used to measure the temperature and salinity of freshwater)

Figure 2. Hydrometer used by the milkfish farmers

The farmers needed an integrated device to solve their problems from the need analysis. Thus, they would not need to bother themselves to bring unintegrated devices. Previous research conducted by Siltri et al. has studied and made a salinity and turbidity measurement tool with only two parameters. So that there are still many who have not studied and researched the incorporation of three water measurement parameters for milkfish cultivation. Therefore, this research aims to create an integrated device ( $\mathrm{pH}, \mathrm{TDS}$, and turbidity) with performance specifications and valid-relevant designs. Thus, farmers could use it to manage their milkfish pond.

\section{Method}

This research applied a Research and Development design. Sugiyono (2012) explains that $R \& D$ is a method to create a certain product and examine its effectiveness. This research created a blueprint of PTS device design ( $\mathrm{pH}, \mathrm{TDS}$, and turbidity). The research stage was done by applying the stages in Figure 2.

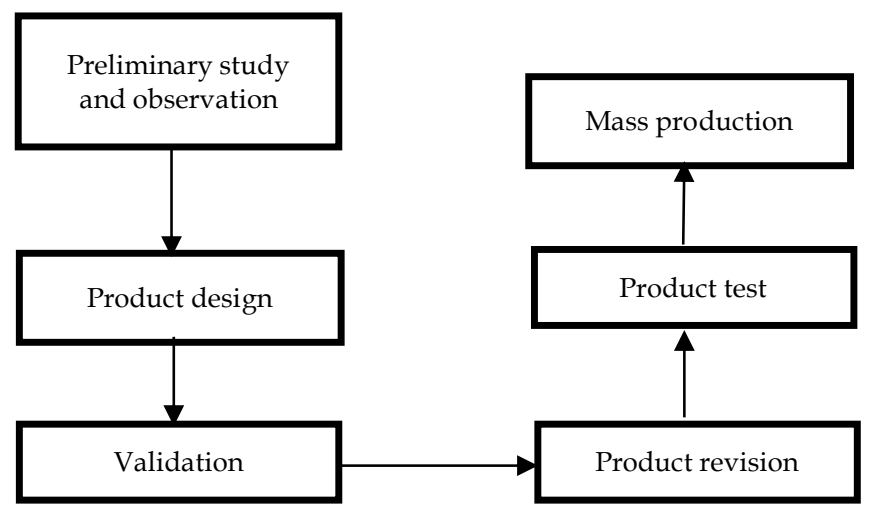

Figure 3. The Stages of this R\&D were Modified from Sugiyono (2012)

\section{Result and Discussion}

The preliminary study begins with observations and interviews with pond farmers in the Bakaran Wetan area, Pati Regency. Then, the observation and interview results showed the farmers' needs. Thus, researchers proceeded to design an integrated $\mathrm{pH}$, TDS, and Salinometer device. They were designed in a blueprint of a device with an LCD to display the measurement.
The developed product required several sensors and other materials: 1) pH DF Robotic sensor, 2) TDS, 3) NTU (turbidity sensor), 4) LCD 2 x 14 12c, 5) Battery 18650, 6) step-up, 7) Bracket battery 18650, and 8) Arduino nano 328 system.

\section{$p H$ Sensor}

This sensor measures $\mathrm{pH}$ based on potential electrochemical occurring in the recognized solution in seawater and the electrode in the glass (the membrane glass) and unrecognized solution outside of the electrode glass (Fajrin, et al. 2020). Due to the thinks layer of the glass bubble, it will interact with the relatively small and active sized hydrogen ions. The glass electrode will measure the electrochemical potential of hydrogen iron, (also known as the potential of hydrogen) (Nandiyanto \& Okuyama, 2011; Pambudi \& Sutanta, 2014). The $\mathrm{pH}$ sensor will measure the potential between the Mercury Chloride (Hg CL) of the comparing electrode and potassium chloride (KCL) that is the solution inside of electrode glass and the potential between the solution and silver electrode. Each solution will provide different voltages based on the ion content in the solution. The sensor will receive it to create the output of analogue signals (Pambudi \& Sutanta, 2014. The electrode function in $\mathrm{pH}$ meter is - to monitor the voltage differences caused by positive ion hydrogen activity $\left(\mathrm{H}^{+}\right)$in the solution (Astria, et al., 2014). The module's mechanism is the $\mathrm{pH}$ sensor will read the electrode sensor's $\mathrm{pH}$ value in the analogue signal. The signal adjustment circuit receives the sensor's output (Suherman \& Suteja, 2020). This design allows the users to monitor $\mathrm{pH}$ without adding an auxiliary circuit into the system (Astria, et al., 2014). Here is figure 3, the applied $\mathrm{pH}$ sensor.

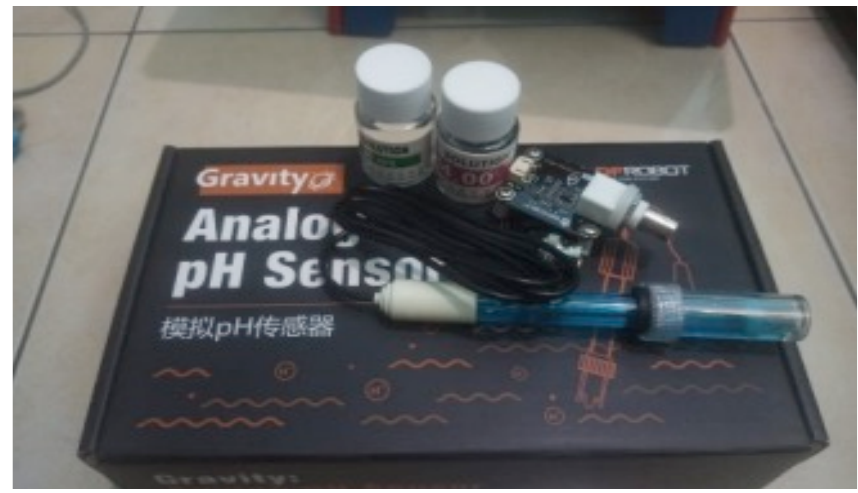

TDS Sensor

Figure 4. $\mathrm{pH}$ Sensor

It is a conductivity, dissolved solids, and salinity sensor application sensor. The researchers used a product from depoinovasi.com by specifying the performance on DC 5 voltage. It is sensitive to conductive materials with a $5.5 \mathrm{~cm}$ liquid depth from the tip of the sensor. It is directly connected to the Arduino 
analogue pin without using the amplifying module. For the installation on the Arduino module, this sensor requires an amplifier circuit to enhance the signals.

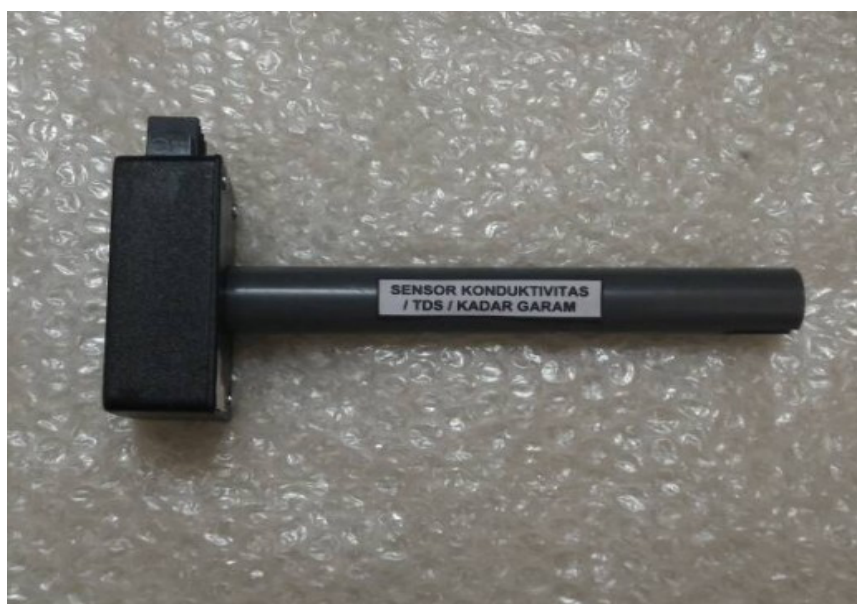

Figure 5. TDS Sensor/Conductivity

\section{NTU (Turbidity Sensor)}

This sensor is also connected to the Arduino system. This Arduino system's principle mechanism is having adjustable analogue signal output mode based on the sensor reading of the threshold due to the Variable Resistor or Potentiometer. This sensor is installed on an additional module as an op-amp to provide outputs in the forms of analogue voltage and digital logic. The sensor uses dispersed light from the LED in which the sensor will read the reflection of the light. Thus, higher turbidity will lead to lower light reflection reading and vice versa. Turbidity is one of the water optic properties. The transparency of a solution determines it. It is caused by the sunlight hitting the water is hindered by water particles and organic-non organic contents in the water. High-turbidity water has low transparency. The turbidity meter's water turbidity could be measured with the NTU scale (Siltri, et al. 2016). Here, Figure 5, showing the turbidity sensor.

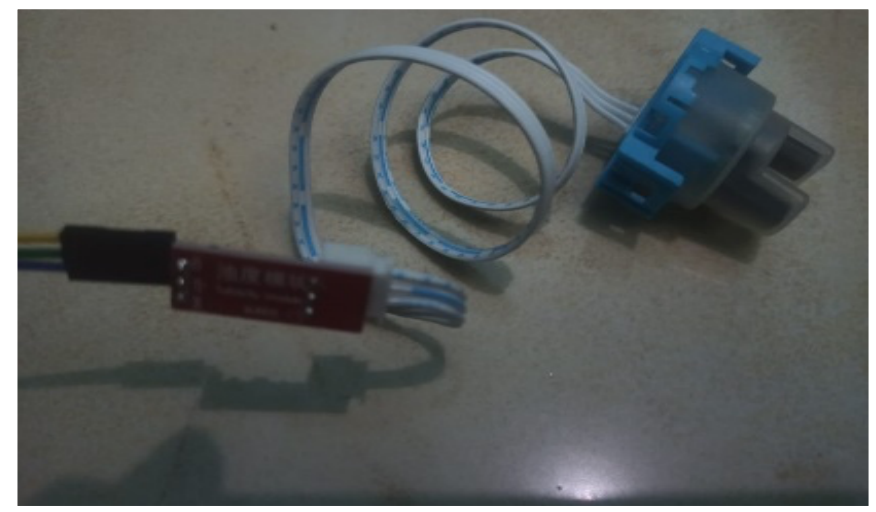

Figure 6. Turbidity Measuring Sensor

\section{LCD $2 \times 1412 C$}

Liquid Cyrstal Display functions as the main display. It has been used in various fields, such as electronic devices - Television, Calculator, or computer screen. The posted display of the LCD uses a dot matrix with the numbers of characters, $2 \times 14,12 \mathrm{C}$. It is very useful to display the device performance statuses. Figure 7 . is the LCD components assembled in displaying the data device of the sensor output.

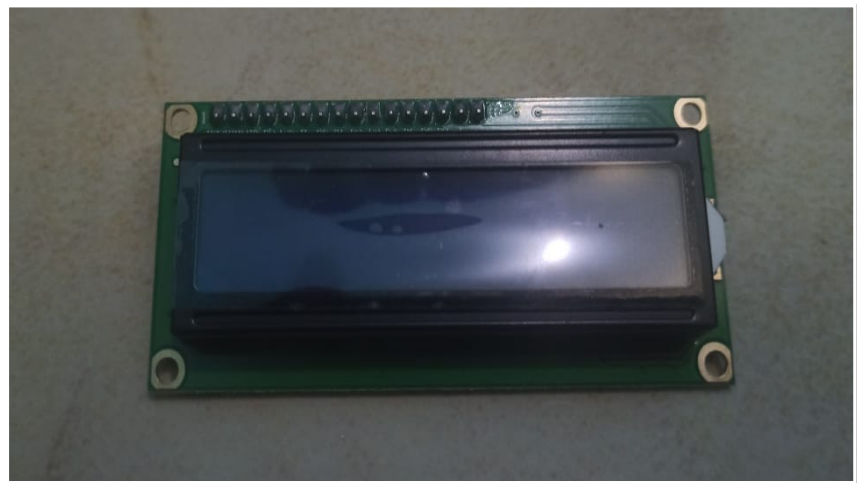

Figure 7. The Assembled LCD Components

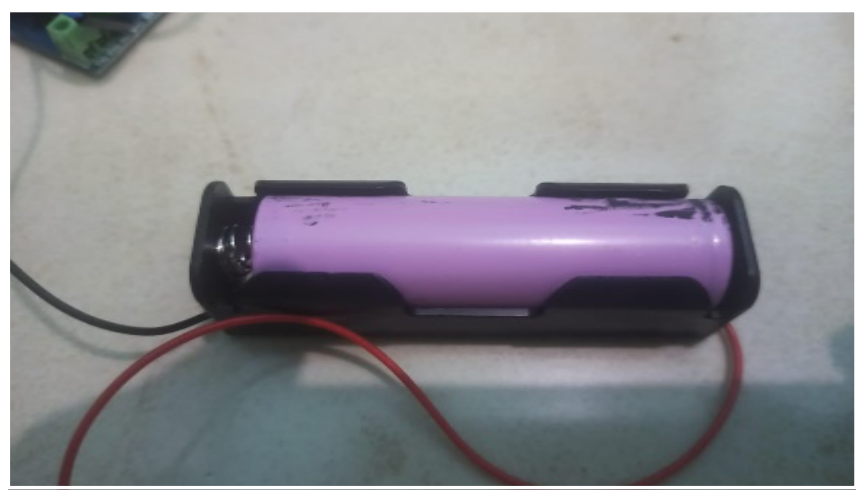

Figure 8. The Used Battery Components

\section{Battery 18650}

This battery is used as the power source of the device. It is a Lithium-Ion (Li-Ion) 18650 typed due to a cylinder's physical size. The number, 18, indicates the diameter, $18 \mathrm{~mm}$ while 650 refers to the battery's height, $65.0 \mathrm{~mm}$. Figure 8 is the battery to support the performance of the circuit maximally as the power source.

\section{Arduino nano 328 system}

Arduino is hardware of electronic circuits functioning as a controller. It is connected by a sensor that provides information about the situation. Then, it is processed and produced an action. The applied Arduino is Atmega 2560 Arduino. This Arduino has 54 digital inputs and outputs. Fourteen pins of the Arduino are used for PWM output while 16 pins are for analogue input, four pins for UART, $16 \mathrm{MHz}$ oscillators, USB connection, a power jack, ICSP, header, and reset button. 


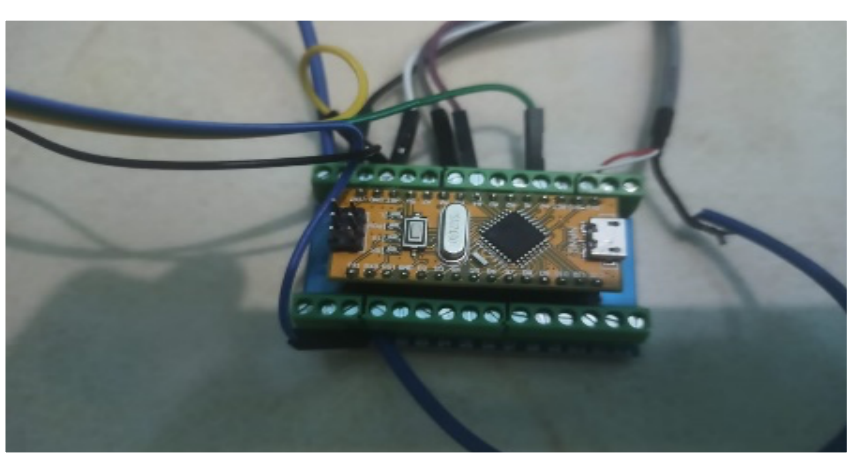

Figure 9. Arduino nano 328 system

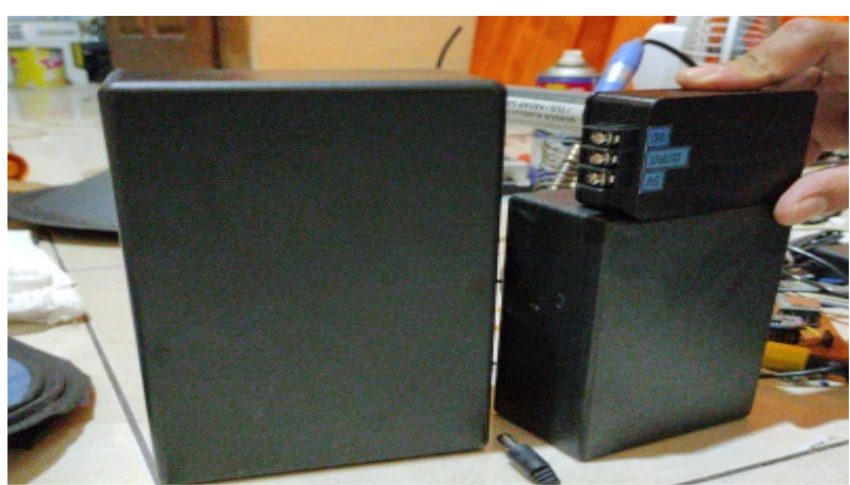

Figure 10. The box and step-up

Various collected components were assembled in a device that consisted of three different device functions. Figure 11 shows that the assembled device software component's circuit is shown while Figure 12 shows the assembled device's appearance in a complete form.

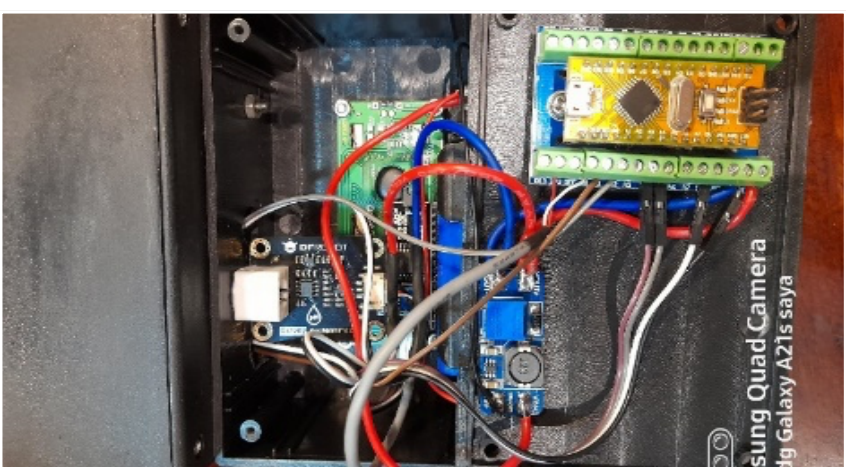

Figure 11. The result of 3 sensor circuit

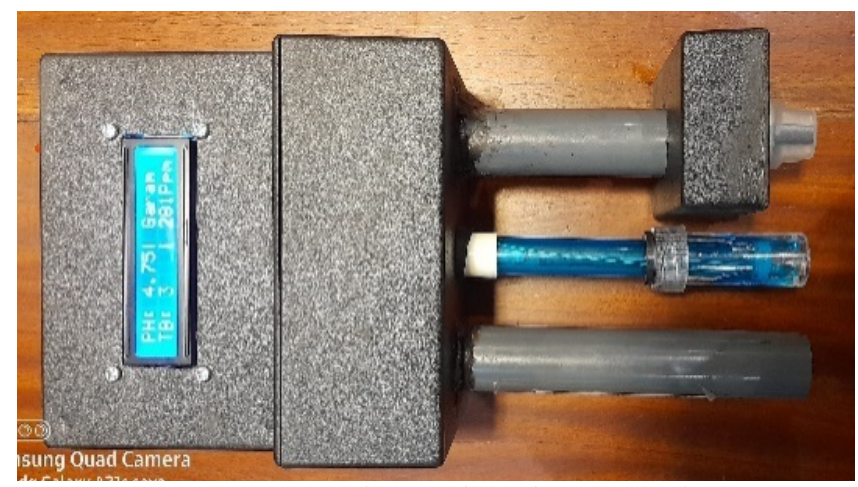

Figure 12. The product design result
The circuit and the system design could be seen systematically in Figure 13.

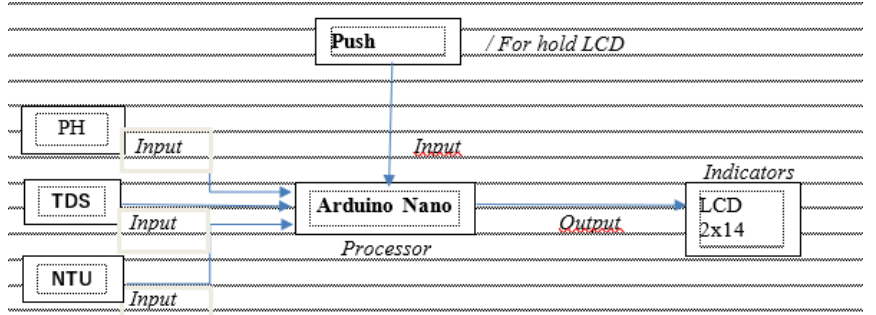

Figure 13. The Hardware Circuit Diagram Blocks pH, Turbidity, and Salinity Measuring Device.

On the other hand, the blueprint of the software can be seen in Figure 14.

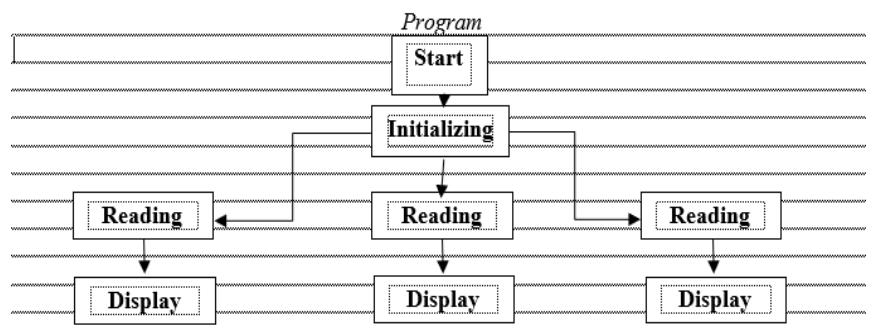

Figure 14. The Software Flowchart of Arduino Control Adjustment in Three Sensors

Experts validated the assembled product design results. The validation was done by a physics lecturer of Universitas Muria Kudus. After being validated and obtaining suggestions for the products, researchers were then revised the products. Based on the experts' suggestions, researchers added on-off buttons to shut the system down. They also provided a hold button to provide pauses during LCD appearance as the water quality recorder.

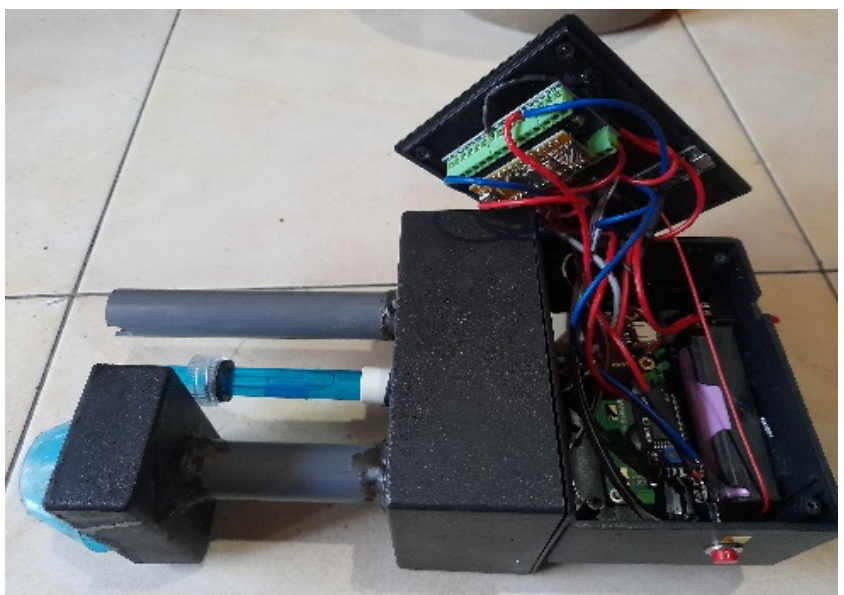

Figure 15. The Display of the Revised Product

The next stage after product revision was running a trial test of the product. However, this research did not conduct until mass production. The trial test was planned to be carried out directly in the pond, but the 
trial test was run on a laboratory scale with various limitations. It was done by taking five pond water samples from different ponds of older milkfish. The trial test results were also done by using the salinity hydrometer of the farmers. The salinity hydrometers were also calibrated by the standardized device $(\mathrm{pH}$ meter, refractometer and TDS). The accuracy determination was done by measuring the $\mathrm{pH}$ system and comparing it with the $\mathrm{pH}$ meter device.

On the other hand, the accuracy system of the turbidity measuring device was done by refractometer. For comparing the salinity measurement or TDS, a TDS meter was used. The measurement accuracy was done with equation 1.

\section{Counting the error percentage}

$$
\text { Error percentage }=\frac{Y n-X n}{Y n} \times 100 \%
$$

Notes $\mathrm{Yn}=$ the actual value (the standard value), $\mathrm{Xn}=$ the read value on the measuring device.

Counting the measurement accuracy system with equation 2.

$$
\% A=1-[(Y n-X n) / Y n] \times 100 \%
$$

(Siltri, et al. 2016)

The calibration is shown in Table 1 . shows that the $\mathrm{pH}$ measurement had a relatively low percentage of error (Err). It was $1.20 \%$ by $4.94 \%$. This $\mathrm{pH}$ measurement system inaccuracy is $2.98 \%$, with an average accuracy of $97.02 \%$. The data shows that this salinity measuring device was reliable to apply in the laboratory or ponds directly.

Table 1. pH Measurement Accuracy

\begin{tabular}{lllll}
\hline \multirow{2}{*}{ Sample } & $\mathrm{pH}$ & & & \\
\cline { 2 - 5 } & $\begin{array}{l}\text { The } \\
\text { assembled } \\
\text { device }\end{array}$ & $\begin{array}{l}\text { The } \\
\text { standardiz } \\
\text { ed device }\end{array}$ & $\begin{array}{l}\text { Err } \\
(\%)\end{array}$ & $\begin{array}{l}\text { Accuracy } \\
(\%)\end{array}$ \\
\hline $\mathrm{A}$ & 7.60 & 7.80 & 2.56 & 97.44 \\
$\mathrm{~B}$ & 7.70 & 8.00 & 3.75 & 96.25 \\
$\mathrm{C}$ & 7.70 & 8.10 & 4.94 & 95.06 \\
$\mathrm{D}$ & 8.00 & 8.20 & 2.44 & 97.56 \\
E & 8.20 & 8.30 & 1.20 & 98.80 \\
Average & & & 2.98 & 97.02 \\
\hline
\end{tabular}

The turbidity sensor's accurate determination was done with the assembled and bastardized devices, the retractor as the comparison. Table 2 shows the turbidity measurement system accuracy. This measurement obtained the average error percentage (Err) from 3.70\% until $4.00 \%$. The average error of the assembled system was $3.88 \%$ and accuracy $96.12 \%$.
Table 2. The Turbidity Measurement System Accuracy

\begin{tabular}{lllll}
\hline \multirow{5}{*}{ Sample } & Turbidity & & & \\
\cline { 2 - 5 } & $\begin{array}{l}\text { The } \\
\text { assembled } \\
\text { device }\end{array}$ & $\begin{array}{l}\text { The } \\
\text { standardiz } \\
\text { ed device }\end{array}$ & $\begin{array}{l}\text { Err } \\
(\%)\end{array}$ & $\begin{array}{l}\text { Accuracy } \\
(\%)\end{array}$ \\
\hline A & 13 & 13.50 & 3.70 & 96.30 \\
B & 12 & 12.50 & 4.00 & 96.00 \\
C & 12 & 12.50 & 4.00 & 96.00 \\
D & 12 & 12.50 & 4.00 & 84.62 \\
E & 13 & 13.50 & 3.70 & 96.30 \\
Average & & & 3.88 & 96.12 \\
\hline
\end{tabular}

The next stage was done to determine the TDS sensor accuracy as a water salinity measuring device. The value of the score was compared with the value of the TDS meter with a denomination, ppm. Based on the table of measurements (Table 3 ), the average score of the error percentage (Err) ranged from $3.29 \%$ to $6.28 \%$. The average error of the assembled system was $4.50 \%$ and accuracy $95.50 \%$.

Table 3. Salinity Measuring System Accuracy

\begin{tabular}{lllll}
\hline \multirow{2}{*}{ Sample } & Salinity & & & \\
\cline { 2 - 5 } & $\begin{array}{l}\text { The } \\
\text { assembled } \\
\text { device }\end{array}$ & $\begin{array}{l}\text { The } \\
\text { standardized } \\
\text { device }\end{array}$ & $\begin{array}{l}\text { Err } \\
(\%)\end{array}$ & $\begin{array}{l}\text { Accuracy } \\
(\%)\end{array}$ \\
\hline A & 441 & 456 & 3.29 & 90.18 \\
B & 443 & 459 & 3.49 & 90.41 \\
C & 444 & 462 & 3.90 & 90.24 \\
D & 442 & 468 & 5.56 & 89.47 \\
E & 448 & 478 & 6.28 & 89.96 \\
Average & & & 4.50 & 95.50 \\
\hline
\end{tabular}

Table 3. shows the developed device accuracy reached the design specification, system performance, and measurement system accuracy of PTS (pH, Turbidity, and Salinity). The developed device facilitates farmers in measuring the pond water quality, consisting of $\mathrm{pH}$, turbidity, and water salinity levels. After being calibrated accurately, the product was tested broadly for five pond samples with different cultivated milkfish. They were milkfish seeds, younger milkfish, and older milkfish. The measurement and trial test instrument during the laboratory scale was done by taking the pond water sample. The water was saved in a $2000 \mathrm{ml}$ - beaker glass. Then, the device was drowned in the water in the beaker glass. After being read by the LCD layer, the hold button could be pressed to find it the pond water quality measurement result. 


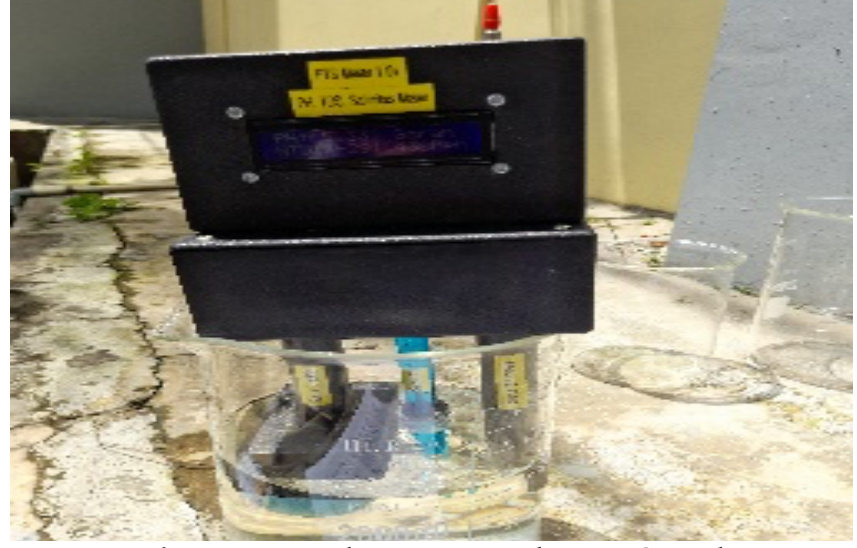

Figure 14. Trial Test Data Taken By Sampling

The data measurement was taken at $30^{\circ} \mathrm{C}$. The average of temperature should be in the acceptable norm for milkfish to live. It should be at the optimal temperature for the fish, between $27^{\circ} \mathrm{C}$ until $30^{\circ} \mathrm{C}$ (Saraswati \& Sari, 2017). The water temperature could influence fish metabolism's life continuity, growth, and reproduction behavior (Effendi, 2003). The measurement trial test could be seen in Table 4 .

The developed device did the measurement. It showed the appropriate acidic level condition $(\mathrm{pH})$. It happened because the sample was taken during the rainy season, and the farmers had not changed the water due to limited condition. Widowati (2004) revealed that a $\mathrm{pH}$ value of 8.5 was better to breed the milkfish in the pond. Hardjowigeno and Widiatmaka (2007) found that milkfish lived in a $\mathrm{pH}$ range from 8 until eight grew better because the $\mathrm{pH}$ was suitable for organism reproduction. Zonneveld (1991) added that temperature and $\mathrm{pH}$ were the regulator factors to influence and determine the metabolism reaction speed in consuming foods. Low $\mathrm{pH}$ value causes mucus clumps on the fish fins. Thus, fish's oxygen supply will be depleted and leads to fish's death (Faisyal, et al. 2016). Ihsanto \& Hidayat (2014) also found that low $\mathrm{pH}$ had lower dissolved oxygen content. It led to decreased oxygen consumption, lowered appetite, and increased breathing activity. Contrary, high $\mathrm{pH}$ value increased the ammonia content. It indirectly endangered the fish. $\mathrm{pH}$ levels of water must be controlled to keep the water condition. It could be done by adding more lime. Lime has roles in increasing the $\mathrm{pH}$ level and releasing hydrogen and phosphate elements (Hardjowigeno, 2002).

Table 4. The Field Test of Pond Water Quality Measurement

\begin{tabular}{|c|c|c|c|c|c|c|c|c|c|c|c|c|c|c|c|}
\hline \multirow{2}{*}{$\begin{array}{l}\text { Water quality } \\
\text { measurement }\end{array}$} & \multicolumn{3}{|l|}{ Pond 1} & \multicolumn{3}{|l|}{ Pond 2} & \multicolumn{3}{|l|}{ Pond 3} & \multicolumn{3}{|l|}{ Pond 4} & \multicolumn{3}{|l|}{ Pond 5} \\
\hline & $\begin{array}{l}\text { Milkfish } \\
\text { Seed }\end{array}$ & BM & BT & $\begin{array}{l}\text { Milkfish } \\
\text { Seed }\end{array}$ & $\mathrm{BM}$ & BT & $\begin{array}{l}\text { Milkfish } \\
\text { Seed }\end{array}$ & BM & BT & $\begin{array}{l}\text { Milkfish } \\
\text { Seed }\end{array}$ & $\mathrm{BM}$ & BT & $\begin{array}{l}\text { Milkfish } \\
\text { Seed }\end{array}$ & $\mathrm{BM}$ & BT \\
\hline $\mathrm{pH}$ & 7.91 & 8.30 & 8.40 & 7.81 & 8.00 & 8.40 & 8.20 & 8.60 & 8.60 & 8.70 & 8.30 & 8.30 & 8.80 & 8.40 & 8.10 \\
\hline $\begin{array}{l}\text { TDS } \\
\text { (salinity)/ppm }\end{array}$ & 442 & 441 & 446 & 438 & 444 & 448 & 437 & 448 & 444 & 440 & 448 & 458 & 440 & 448 & 449 \\
\hline $\begin{array}{l}\text { Turbidity } \\
\text { (NTU) }\end{array}$ & 11 & 11 & 13 & 11 & 12 & 13 & 11 & 12 & 13 & 11 & 12 & 14 & 11 & 13 & 14 \\
\hline
\end{tabular}

The salinity measurement showed the salinity of the water (Wahyudin \& Merdekawati, 2019). The salinity range measurement did not show the significant variation of each sample pond. It showed the water salinity condition was still appropriate. Different salinity levels influenced fish growth (Hamed, et al. 2016). The salinity level of milkfish seed pond was lower than the older milkfish. It was due to the seeds only ate phytoplankton and zooplankton. Moreover, plankton only lives in lower salinity water (Rangka \& Asaad, 201).

For measuring the Salinity, Total Dissolved Solid sensor was used. TDS refers to the number of dissolved solids in a solution (both organic or non-organic). TDS describes the dissolved substance in a denomination of part per million $(\mathrm{ppm})$ or milligram per litre $(\mathrm{mg} / \mathrm{L})$ found that clarity was influenced by weather, measuring time, and turbidity (Garai, et al. 2018). Salinity condition was influenced by rainfall and temperature (Effendi, 2003). They cause the salinity level decreases or increases. Higher rainfall rate and freshwater penetration into the pond decrease the salinity.
On the other hand, when the temperature increases, the salinity also increases (Sustianti, et al. 2014)(Irawan \& Handayani, 2020). Lower temperature leads to lower salinity level. It could be prevented by adding water to the pond. The next parameter is turbidity. It was checked by using a turbidity sensor. The water quality with the appropriate condition is the minimum requirement of milkfish cultivation. With proper clarity, it is important to keep the quality stable. The colour of excellent water is light brown. It is in line with Ariawan (2005), He found that an excellent colour for cultivating milkfish was light brown because it had much plankton. This condition was usually found in young milkfish pond. The water condition was much brighter for milkfish seeds with a lot of phytoplankton as the food for them. For older milkfish, the pond watercolour was darker brown and more feculent.

The limitation of this research is that it only reaches the product trial step and has not yet led to mass production. A more detailed calibration is needed, and further test should be applied to develop the product. 
However, generally, this product is reliable and applicable because the results were valid and relevant. Henceforth, this tool can be used by milkfish pond farmers in checking the quality of water in their pond cultivation business.

\section{Conclusion}

This PTS device development integrated several sensors with Arduino nano 328 system, $\mathrm{pH}$ meter analog, turbidity, and salinity measurement sensors complemented by Liquid Crystal Display and battery. They are connected by data cable. Based on the development, a relevant and valid product design was obtained to measure the $\mathrm{pH}$, salinity, and turbidity conditions of milkfish cultivation.

\section{Acknowledgments}

Thank you to the dean of FKIP and elementary school teacher education students at Universitas Muria Kudus for helping with this research. Thank you to the milkfish pond cultivators in Bakaran Juwana Village who have been willing to help with this research.

\section{References}

Alava, V. R. (1998). Effect of salinity, dietary lipid source, and level on growth of milkfish (Chanos chanos) fry. Aquaculture. $\quad 167(3-4), \quad 229-236$. http://doi.org/10.1016/s0044-8486(98)00317-2

Andriyanto, S. (2013). Kondisi terkini budidaya ikan bandeng di kabupaten Pati, Jawa Tengah. Media Akuakultur. $\quad 8(2)$; 139-144. http://dx.doi.org/10.15578/ma.8.2.2013.139-144

Ariawan, K. (2005). Peningkatan produksi udang merguiensis melalui optimasi dan pengaturan oksigen. Laporan Tahunan. BBPBAP Jepara.

Astria, F., Subito, M., \& Nugraha, D. W. (2014). Rancang Bangun Alat Ukur $\mathrm{pH}$ dan Suhu Berbasis Short Message Service (SMS) gateway. Jurnal MEKTRIK. 1(1).47-55. Retrieved from http://jurnal.untad.ac.id/jurnal/index.php/Mekt rik/article/view/3590

Cai, J., Zhou, X., Yan, X., Lucentea, D., \& Lagana, C. (2019). Top 10 species groups in global aquaculture 2017. Rome: Fisheries and Aquaculture Department, Food and Agriculture Organization of the United Nations. Retrieved from https://www.fao.org/documents/card/en/c/ca5 224en/

Edwards, P. (2015). Aquaculture environment interactions: past, present and likely future trends. Aquaculture. 447, https://doi.org/10.1016/j.aquaculture.2015.02.001
Effendi, H. (2003). Telaah kualitas air, bagi pengelolaan sumber daya dan lingkungan perairan. Kanisius.

Esmiyati, Damayanti C., Asfiah, N., Pamelasari SD. (2012). Pembudidayaan Bandeng Juwana Berbasis Kearifan Lokal sebagai muatan Lokal untuk menumbuhkan Sikap Konservasi Siswa. Unnes Science Education Journal. 1(1); 21-33. https://doi.org/10.15294/usej.v1i1.850

Faisyal, Y., Rejeki, S., \& Widowati, L. L.. (2016). Pengaruh Padat Tebar Terhadap Pertumbuhan Dan Kelulushidupan Ikan Bandeng (Chanos Chanos) Di Keramba Jaring Apung Di Perairan Terabrasi Desa Kaliwlingi Kabupaten Brebes. Journal of Aquaculture Management and Technology. 5(1), 155-161. Retrieved from

https://ejournal3.undip.ac.id/index.php/jamt/ar ticle/view/11778

Fajrin, H. R., Zakiyyah, U., \& Supriyadi, K. (2020). Alat Pengukur $\mathrm{pH}$ Berbasis Arduino. Medika Teknika: Jurnal Teknik Elektromedik Indonesia. 1(2), 35-43. Available from https://core.ac.uk/download/pdf/323997631.pdf

Garai, A. N., Wahab, I. H. A., \& Sardju, A. P. (2018). Sistem Akuisisi Data Salinitas Pada Perairan Laut. Jurnal PROtek. 5(1).18-23. http://dx.doi.org/10.33387/protk.v5i1.610

Hamed, S. S., Jiddawi, N. S., \& Poj, B. (2016). Effect of salinity levels on growth, feed utilization, body composition, and digestive enzymes activities of juvenile silver pompano Trachinotus blochii. Int. J. Fish. Aquat. Stud. 4(4). 279-283. Retrieved from https://www.fisheriesjournal.com/archives/?yea $r=2016 \& v o l=4 \&$ issue $=6 \&$ part $=$ D\&ArticleId $=1003$

Hanke, I., Ampe, B., Kunzmann, A., Gärdes, A., \& Aerts, J. (2019). Thermal Stress Response of Juvenile Milkfish (Chanos Chanos) Quantified by Ontogenetic and Regenerated Scale Cortisol. Aquaculture. 500, 24-30. https://doi.org/10.1016/j.aquaculture.2018.09.016

Hardjowigeno, S and Widiatmaka. (2007). Evaluasi Kesesuaian Lahan dan Perancangan Tataguna Lahan. Gadjah Mada University Press.

Hardjowigeno, S. (2002). Ilmu Tanah. Akademika Pressindo. Jakarta.

Hu, Y. C., Kang, C. K., Tang, C. H., \& Lee, T. H. (2015). Transcriptomic analysis of metabolic pathways in milkfish that respond to salinity and temperature changes. PLoS One.10(8); e0134959. https://doi.org/10.1371/journal.pone.0134959

Ihsanto, E., \& Hidayat, S. (2014). Rancang Bangun Sistem Pengukuran $\mathrm{pH}$ meter dengan Menggunakan Mikrokontroller Arduino Uno. Jurnal Teknologi Elektro. 5(3).130-137. https://dx.doi.org/10.22441/jte.v5i3.769

Irawan, D., \& Handayani, L. (2020). Studi kesesuaian kualitas perairan tambak ikan bandeng (Chanos 
chanos) di Kawasan Ekowisata Mangrove Sungai Tatah. e-Journal BUDIDAYA PERAIRAN. 9(1).10-18. https://doi.org/10.35800/bdp.9.1.2021.30319

Mariyam, S., Romdon, S., \& Kosasih, E. (2017). Teknik Pengukuran Oksigen Terlarut. Buletin Teknik Litkayasa Sumber Daya dan Penangkapan. 2(1), 45-47. http://dx.doi.org/10.15578/btl.2.1.2004.45-47

Mirera, O. D. (2011). Trends in exploitation, development, and management of artisanal mud crab (Scylla serrata-Forsskal-1775) fishery and small-scale culture in Kenya: An overview. Ocean $\mathcal{E}$ coastal management. 54(11), 844-855. https://doi.org/10.1016/j.ocecoaman.2011.08.001

Nandiyanto, A. B. D., \& Okuyama, K. (2011). Progress in developing spray-drying methods to produce controlled morphology particles: From the nanometer to submicrometer size ranges. Advanced $\begin{array}{lll}\text { Powder Technology. 22(1), 1-19. } & \text {. }\end{array}$ https://doi.org/10.1016/j.apt.2010.09.011

Pambudi, P. E., \& Sutanta, E. (2014). Identifikasi Daging Segar dan Busuk Menggunakan Sensor Warna RGB dan PH Meter Digital. Jurnal Teknologi Technoscientia. 046-053. https://doi.org/10.34151/technoscientia.v7i1.605

Rachmatun, S., \& Mujiman, A. (2011). Budidaya Udang Windu. Cetakan XIII, PT Penebar Swadaya, Jakarta.

Rangka, N. A., \& Asaad, A. I. J. (2010). Teknologi budidaya ikan bandeng di sulawesi selatan. In Prosiding Forum Inovasi Teknologi Akuakultur. (pp. 187-203). Retrieved From: http://ejournalbalitbang.kkp.go.id/index.php/fita/article/view/ $\underline{6377}$

Riani, R., I, Indra. (2016). Analisis Efisiensi Teknis Usahatani Tambak Ikan Bandeng (Chanos Chanos, F) Di Kabupaten Aceh Utara. Jurnal Agrisep. 17(1). 1-17 Retrieved from http://jurnal.unsyiah.ac.id/agrisep/article/view/ 7460

Salmin, O. T. (2005). Kebutuhan Oksigen Biologi (BOD) Sebagai Salah Satu Indikator Untuk Menentukan Kualitas Perairan. Oseana. XXX, 3, 21-26.

Saraswati, S. A., \& Sari, A. H. W. (2017). Water Quality Assessment and Conformity Assessment of Ponds in The Development Effort of Milkfish (Chanos Chanos Forskal) Cultivation In Pemuteran Village, Gerokgak District, Buleleng Regency. Samakia: Jurnal Ilmu Perikanan. 8(2), 01-05. https://doi.org/10.5281/jsapi.v8i2.259

Shirley, Sarah. (2005). Assessments of Seven Refractometers for Evaluating Wildland Fire Retardants. US: Departement of Agriculture.

Siltri, D. M., Yohandri, Y., \& Kamus, Z. K. Z. (2016). Pembuatan Alat Ukur Salinitas Dan Kekeruhan Air Menggunakan Sensor Elektroda Dan Ldr. Sainstek: Jurnal Sains dan Teknologi. 7(2), 126-139. http://dx.doi.org/10.31958/js.v7i2.133
Sugiyono. (2012). Metode Penelitian Kuantitatif, Kualitatif, dan RED. Bandung: Alfabeta; 2012

Suherman, Z. L., \& Suteja, B. R. (2020). Implementasi Teknologi Internet of Things Untuk Pemantauan Temperatur Udara, Kelembapan Udara, Debit dan PH Air pada Media Tanam Hidroponik. Jurnal STRATEGI-Jurnal Maranatha. 2(2), 369-376. Retrieved from http://strategi.itmaranatha.org/index.php/strate gi/article/view/188

Sustianti, A. F., \& Suryanto, A. (2014). Kajian Kualitas Air dalam Menilai Kesesuaian Budidaya Bandeng (Chanos chanos Forsk) di Sekitar PT Kayu Lapis Indonesia Kendal. Journal of Management of Aquatic Resources. 3(2), 1-10. https://doi.org/10.14710/marj.v3i2.4835

Tang, C. H., Wu, W. Y., Tsai, S. C., Yoshinaga, T., \& Lee, T. H. (2010). Elevated $\mathrm{Na}+/ \mathrm{K}+-A T P a s e$ responses and its potential role in triggering ion reabsorption in kidneys for homeostasis of marine euryhaline milkfish (Chanos chanos) when acclimated to hypotonic fresh water. Journal of Comparative Physiology B. 180(6); 813-824. https://doi.org/10.1007/s00360-010-0458-x

Taslihan, A, Supito, Erik Sutikno, R.B. Callinan. (2005). Teknik Budidaya Udang Secara Benar, Balai Besar Pengembangan Budidaya Air Payau. Ditjen Perikanan Budidaya, Jakarta.

Wahyudin, Y., \& Merdekawati, D. (2019). Water quality at silvoaquaculture pond in Indramayu regency. In IOP Conference Series: Earth and Environmental Science. 383 (1) p. 012033). IOP Publishing. http://dx.doi.org/10.1088/17551315/383/1/012033

Widowati, L. L. (2004). Suitability Analysis of Pond's Water Quality in Demak Residence Based on Primary Productivity Using Remote Sensing (Doctoral dissertation, program Pascasarjana Universitas Diponegoro).

Zonneveld, N., Huisman, E. A., \& Boon, J. H. (1991). Prinsip-prinsip Budidaya Ikan. PT Gramedia Pustaka Utama. 